\title{
PRINCIPALS' MANAGEMENT TECHNIQUES AND STUDENTS' ACADEMIC PERFORMANCE IN SECONDARY SCHOOLS ILORIN EAST LGA, KWARA STATE
}

\author{
Olubukola James Ojo (Ph.D) \\ Department of Educational Management, University of Ilorin, Ilorin, Nigeria, \\ martins_small79@yahoo.com
}

\begin{abstract}
The development and usability of management techniques by most organizations have made them indispensable tools in solving organizational problems. It is against this background that this study investigated principals' management techniques and students' academic performance in secondary schools in Ilorin East Local Government Area of Kwara State. The study adopted a descriptive research design. The population of the study comprised of all the 28 public secondary schools in Ilorin East. Ten secondary schools were randomly selected for this study. Purposive sampling technique was used to select eight teachers in the core subject areas used for this study. A researcher-designed instrument titled "Principals" Management Techniques Questionnaire" (PMTQ) and a proforma titled "Students' Academic Performance Proforma" (SAPP) was used to collect students result in the four core subject areas used for this study. The validity and the reliability of the instrument were ascertained and the co-efficient of reliability was 0.72 which was considered high enough for this study. The result from the research question showed that motivational management technique was the most proffered technique used by principals in Ilorin East Local Government Area with a mean score of 3.62 while the record keeping technique had the lowest mean score of 2.38. Findings showed that there was a significant relationship between principals' management techniques and students' academic performance in Ilorin east local government Area of Kwara State $(\mathrm{r}=.641$; $\mathrm{p}<.05)$. In line with these findings, it was recommended that principals should try as much as possible to adopt the suitable techniques applicable in a particular situation for the day to day running of the school and teachers should be involved in the formulation of the objectives of the school for the effectiveness and achievement of the school goals.
\end{abstract}

Keywords: Principals' Management Techniques, Students' Academic Performance, Management by Objectives, Motivation, Supervisory

\section{INTRODUCTION}

Every secondary school in Nigeria is headed by the principal, who is often referred to as the chief executive charged with the responsibilities of overseeing the day to day administration and management of the schools under his jurisdiction. No wonder they are often been regarded as both the academic and administrative head of secondary schools in Nigeria. The principals are saddled with the responsibilities of ensuring the smooth running of all the activities within the school using different approaches, methods and techniques in order for the realization of educational goals and objectives.

Management techniques are products of management theories which were developed by management practitioners. The emergence of management theories led to the introduction of management techniques. Different professions have different techniques although there are general management techniques that have been developed by management theorists and practitioners in solving management related issues. Management techniques serve as methods of ensuring proper

Citation: Ojo, O. J. (2018). Principals' Management Techniques and Students' Academic Performance in Secondary Schools Ilorin East Lga, Kwara State. Anatolian Journal of Education, 3(1), 21-30. https://doi.org/10.29333/aje.2018.312a 
administration of the school with the aim of assisting the school principals to develop a productive workplace.

In the field of management, there is no single management technique that works in all situations because situation differs. It is based on this assertion that it is imperative for school managers to become familiar with more than one management technique for making plans and decisions. Research in the past have proved that a number of these management techniques if put into effective use can aid the efficiency and effectiveness of the school. Management techniques is the ability of the principal in a secondary school to use a wide range of methods such as management by objective technique (MBO), supervisory technique, record keeping technique and motivational technique to achieve the objectives of secondary education.

Students' academic performance depends on a number of factors and as such the effective utilization of management techniques by school principals may bring about improved students' performance in public examinations. Students' academic performance refers to as the observable and non-observable outcome of teaching and learning activities. Various researchers in the field of education were of the opinion that students' academic performance refers to the final grade which a student obtained after exposure to teaching and learning activities on his or her cognitive, affective and psychomotor domains in both internal and external examinations.

It is based on this background that this study investigated principals' management techniques as a correlate of students' academic performance in secondary schools in Ilorin East Local Government Area of Kwara State. The choice of this state stem from the fact that the researcher observed that the level of performance of students in public examinations is quite low. In the quest to know the factors responsible for these abysmal low performances among the students led the researcher to carry out this study focusing on this state.

\section{Review of Related Literature}

Bua, Tyokyya and Kwaghbo (2016) carried out a study which assessed the application of MBO in the administration of UBE programme in Makurdi Education Zone. The survey research design was employed in carrying out the study. The findings of their study revealed that principals' involvement of teachers in decision-making in technical issues has significant effects on administration of UBE schools' programme. Evans-Obinna (2016) carried out a study on management by objective: a top down planning technique for effective Nigerian secondary school management in the $21^{\mathrm{st}}$ century. The paper was expository in nature and the findings of the study indicated that both teachers and principals were of the view that all the elements of MBO are relevant and beneficial in achieving continuous improvement in secondary school management. Nwite (2016) carried out a study on principal's application of management by objective in secondary schools in Ebonyi State, Nigeria. The findings showed that there was no significant difference in the mean ratings between the male and female principals in the application of management by objective in schools.

A study to investigate principals' supervisory aptitude of teachers' work performance in Delta State secondary schools, Nigeria was conducted by Nakpodia (2011). The results of the study showed that teachers' performance in secondary schools is significantly dependent on the aptitude of the principals to effectively conduct adequate and valuable supervision which validates the importance of discipline, recordkeeping and teaching aids. A study on supervisory strategies and effective instructional delivery in some secondary schools in Etche Local Government Area, Rivers State, Nigeria was conducted by Ubulom, Nnunukwe \&Dambo (2016). The study adopted correlational research design. The study found that supervisors' adequate visitations to observe teaching/learning process, organize conferences and workshops for teachers as aspects of supervisory strategies 
influenced teachers' effective instructional delivery in secondary schools in Etche Local Government Area of Rivers State and there was significant relationship between supervisors' visitations to observe teaching/learning process as an aspect of supervisory strategies and teachers' effective instructional delivery in secondary schools.

A study on the Strategies for Motivation of Teachers for Effectiveness amid Universal Basic Education (UBE) Programme Implementation in Nigeria was carried out by Ige (2014). The paper showed that allowing teachers to participate in decision making, attending to teachers' personal and on the job problems, recognizing, praising and rewarding teachers with outstanding performance, assigning responsibilities to teachers, providing incentives for teachers, improving school environment, providing instructional materials for teachers, regular promotion of teachers, sponsoring teachers to conferences, seminars, and workshops, prompt payment of teachers' salaries and allowances, payment of special salary for teachers, as well as the professionalization of teaching.

Oluwole and Ivagher (2015) carried out a study on record keeping and effective management of secondary schools in Zone B Senatorial District of Benue State, Nigeria. The descriptive survey design was adopted. The study revealed that historical records have significant impact on information dissemination and financial records have significant impact on accountability in Zone B Senatorial District of Benue State.

\section{Statement of the Problem}

Despite extensive researches, discussions and debates on how students' academic performance could be improved upon in most secondary schools in Nigeria, the failure rate in public examination is still on the increase. Overtime, the performance of students in Ilorin East Local Government Area of Kwara State in public examinations is dwindling owing to the fact that the school has neglected some major factors aiding the growth in performances of students. The root of these factors is attributed to management and the techniques adopted. Ineffective supervisory technique, poor record keeping technique and absence of motivational technique by principals of secondary schools could have a negative impact on the performance of students in secondary schools.

\section{Purpose of the Study}

The major purpose of this study was to examine the relationship that exists between principals' management techniques and students' academic performance in Ilorin East Local Government Area of Kwara State. Specifically, management by objective technique (MBO), supervisory technique, record keeping technique and motivational technique were examined as components of principals' management techniques. The extent to which each of these components contributes to students' academic performance was determined in this study.

\section{Research Questions}

1. What is the most preferred management technique used by principals of Secondary schools in Ilorin East Local Government Area of Kwara State?

2. What is the level of students' academic performance in secondary schools in Ilorin East Local Government Area of Kwara State?

\section{Research Hypotheses}

One main and four operational hypotheses were formulated and tested in this study.

Ho: There is no significant relationship between principals' management techniques and students' academic performance in Ilorin East Local Government Area of Kwara State. 
$\mathrm{Ho}_{1}$ : There is no significant relationship between principals' management by objectives technique and students' academic performance in Ilorin East Local Government Area of Kwara State.

$\mathrm{Ho}_{2}$ : There is no significant relationship between principals' record keeping technique and students' academic performance in Ilorin East Local Government of Kwara State.

Ho3: There are is no significant relationship between principals' supervisory technique and students' academic performance in Ilorin East Local Government Area of Kwara State.

Ho4: There is no significant relationship between principals' motivational technique and students' academic performance in Ilorin East Local Government Area of Kwara State.

\section{METHOD}

\section{Research Design}

The study adopted a descriptive research design. This is because descriptive research design focused on the events the way they occur without any modifications from external source. In the work of Kochlar (2005) descriptive research is a design in which information gotten from subsets of the sample of the population describe situation as they exist.

\section{Participants}

The population for the study comprised all secondary school teachers in Ilorin East Local Government Area, Kwara State. There are 28 senior secondary schools in the Local Government, 10 secondary schools were randomly selected. Purposive sampling technique was used to select eight teachers in each school in the four core subject area used. The researcher considered the sample enough for this study because only teachers in the four core subject areas whose subject results were used could give response to the items in the questionnaire.

\section{Research Instruments}

A self-designed questionnaire titled: Principals' Management Techniques questionnaire (PMTQ) and Students' academic performance proforma in the four core subject area i.e English, Mathematics, Biology and Economics was used for collecting students' results in West African Certificate Examination from 2011/12 academic session up to 2013/14 in the sampled schools. Data from 2014/15 to 2016/17 session were not available from the Ministry as at the time of carrying out this study. The items on the questionnaire were rated using the four-point likert-type rating scale of Strongly Agree, Agree, Disagree and Strongly Disagree.

\section{Validity and Reliability of the Instruments}

In order to ascertain the validity of the instruments used for this study, copy of the drafted questionnaire and proforma was given to the project supervisor and two other lecturers in the Department of Educational Management, University of Ilorin for scrutiny. The opinions, amendments and suggestions of the experts were incorporated into the final instrument that was administered to the respondents. The reliability of the instrument was ascertained through test-re-test method. The instrument was administered to 15 respondents who are not part of the schools selected for this study. The issue of normality test was followed by the researcher in the process of carrying out the reliability. Thereafter, the same process was followed again after an interval of two weeks of the first administration on the same set of respondents. Thereafter, Pearson product-moment correlation statistic was used to determine the correlation co-efficient of the two sets of scores at 0.05 level of significance which yielded 0.72 which was considered high enough for the study. 


\section{Procedure for Data Collection}

The instrument for the study was personally administered by the researcher to the respondents in the sampled schools in order to ensure effectiveness in the rate of return and also to give clarity on the areas where there are ambiguities.

\section{Methods of Data Analysis}

Descriptive statistics of mean, standard deviation and rank order was used to answer the two research questions raised for the study. Pearson product-moment correlation statistics was used to test all the hypotheses formulated in the study at 0.05 level of significance.

\section{FINDINGS}

Research Question 1: What is the most preferred management technique used by principals of Secondary schools in Ilorin East Local Government Area of Kwara State?

Table 1

Mean rating and standard deviations of management techniques mostly adopted by principals of secondary schools in Ilorin East Local Government

\begin{tabular}{llllll}
\hline Management Techniques & $\mathrm{N}$ & \multicolumn{2}{c}{ Mean } & Std. deviation & Rank \\
\hline Management by objectives & 80 & 3.13 & & 1.47 & $3^{\text {rd }}$ \\
Record keeping & 80 & 2.38 & 1.10 & $4^{\text {th }}$ \\
Supervisory & 80 & 3.27 & 1.68 & $2^{\text {nd }}$ \\
Motivation & 80 & 3.62 & 1.75 & $1^{\text {st }}$ \\
Valid N (list wise) & 80 & & & \\
\hline
\end{tabular}

Table 1 shows the mean and standard deviations of the mostly preferred management techniques adopted by principals of secondary schools in Ilorin East local government area of Kwara State. The motivational management technique had the highest mean score of 3.62 while the record keeping technique had the lowest mean score of 2.38. This shows that the motivational technique is the mostly preferred technique followed by supervisory technique $(\mathrm{m}=3.27)$, Management by objectives technique $(\mathrm{m}=1.47)$.

Research Question 2: What is the level of students' academic performance in secondary schools in Ilorin East Local Government Area, Kwara State?

Table 2

Mean and Standard Deviation of the Level of Students' Academic Performance in Mathematics, English Language, Biology, and Economics

\begin{tabular}{lllll}
\hline S/N & Subject & $\mathrm{X}$ & $\mathrm{SD}$ & Decision \\
\hline 1. & Mathematics & 1.89 & .75 & Average \\
2. & English Language & 1.56 & .53 & Low \\
3. & Economics & 1.85 & .44 & Average \\
4. & Biology & 1.77 & .53 & Average \\
\hline
\end{tabular}

Source: Fieldwork, 2016

$\begin{array}{ll}\frac{\text { Key }}{\mathrm{X}} & \\ 1.00-1.59 & \text { Low } \\ 1.60-2.59 & \text { Average } \\ 2.60 .5 .00 & \text { High }\end{array}$


Table 2 shows the mean and standard deviation of the level of students' academic performance in Mathematics, English Language, Economics and Biology were found to be 1.89, 1.56, 1.85 and 1.77 respectively. Therefore, students' academic performance in Mathematics, Economics and Biology were found to be average overall.

\section{Hypothesis Testing}

Ho: There is no significant relationship between principals' management techniques and students' academic performance in Ilorin East Local Government Area, Kwara State

Table 3

Principals' Management Techniques and Students' Academic Performance

\begin{tabular}{lllllllll}
\hline Variable & & $\mathrm{N}$ & $\overline{\mathrm{X}}$ & $\mathrm{SD}$ & $\mathrm{Df}$ & Cal r-value & P-value & Decision \\
\hline $\begin{array}{l}\text { Principals' } \\
\text { Techniques }\end{array}$ & Management & 80 & 2.96 & .53 & & & & \\
$\begin{array}{l}\text { Students' Academic } \\
\begin{array}{l}\text { Performance } \\
\text { *Significant } \mathrm{p}<.05\end{array}\end{array}$ & 80 & 2.41 & .70 & 78 & .641 & .000 & Ho Rejected \\
\hline
\end{tabular}

Table 3 shows the calculated r-value of .641 while p-value $(0.000)$ is less than the significance level (0.05) for 78 degrees of freedom. Therefore, the hypothesis which states that there is no significant relationship between principals' management techniques and students' academic performance in Ilorin East Local Government Area, Kwara State is rejected. This therefore revealed that there is significant relationship between principals' management techniques and students' academic performance in Ilorin East Local Government Area, Kwara State.

$\mathrm{Ho}_{1}$ : There is no significant relationship between principals' management by objectives techniques and students' academic performance in Ilorin East Local Government Area, Kwara State

Table 4

Principals' Management by Objectives Technique and Students' Academic Performance

\begin{tabular}{llllllll}
\hline Variable & $\mathrm{N}$ & $\overline{\mathrm{X}}$ & $\mathrm{SD}$ & $\mathrm{Df}$ & $\mathrm{Cal}$ r-value & P-value & Decision \\
\hline $\begin{array}{l}\text { Principals } \\
\text { Management by }\end{array}$ & 80 & 2.57 & .67 & & & & \\
$\begin{array}{l}\text { Objectives Technique } \\
\text { Students' Academic }\end{array}$ & 80 & 2.41 & .70 & & & & \\
$\begin{array}{l}\text { Performance } \\
\text { *Significant } \mathrm{p}<.05\end{array}$ & & & & & & & \\
\end{tabular}

Table 4 shows the calculated r-value of .501 while p-value $(0.001)$ is less than the significance level (0.05) for 78 degrees of freedom. Therefore, the hypothesis which states that there is no significant relationship between principals' management by objectives technique and students' academic performance in Ilorin East Local Government Area, Kwara State is rejected. This therefore showed that there is significant relationship between principals' management by objectives technique and students' academic performance in Ilorin East Local Government Area, Kwara State. $\boldsymbol{H o}_{2}$ :

There is no significant relationship between principals' record keeping techniques and students' academic performance in Ilorin East Local Government Area, Kwara State 
Table 5

Principals' Record Keeping Technique and Students' Academic Performance

\begin{tabular}{llllllll}
\hline Variable & $\mathrm{N}$ & $\overline{\mathrm{X}}$ & $\mathrm{SD}$ & $\mathrm{Df}$ & $\mathrm{Cal}$ r-value & P-value & Decision \\
\hline $\begin{array}{l}\text { Principals' Record } \\
\text { Keeping Technique }\end{array}$ & 80 & 2.45 & .69 & & & & \\
& & & & 78 & .556 & .001 & Ho Rejected \\
$\begin{array}{l}\text { Students' Academic } \\
\text { Performance }\end{array}$ & 80 & 2.41 & .70 & & & & \\
\hline *Significant $p<.05$ & & & & & &
\end{tabular}

*Significant $\mathrm{p}<.05$

Table 5 shows the calculated r-value of .556 while p-value $(0.001)$ is less than the significance level (0.05) for 78 degrees of freedom. Therefore, the hypothesis which states that there is no significant relationship between principals' record keeping technique and students' academic performance in Ilorin East Local Government Area, Kwara State is rejected. This shows that a significant relationship existed between principals' management record keeping technique and students' academic performance in Ilorin East Local Government Area, Kwara State.

$\mathrm{Ho}_{3}:$ There is no significant relationship between principals' supervisory techniques and students' academic performance in Ilorin East Local Government Area, Kwara State

Table 6

Principals' Supervisory Technique and Students' Academic Performance

\begin{tabular}{lllllllll}
\hline Variable & & $\mathrm{N}$ & $\overline{\mathrm{X}}$ & $\mathrm{SD}$ & $\mathrm{Df}$ & Cal r-value & P-value & Decision \\
\hline $\begin{array}{l}\text { Principals' } \\
\text { Technique }\end{array}$ & Supervisory & 80 & 2.52 & .76 & & & & \\
& & & & & & & \\
Students' & Academic & 80 & 2.41 & .70 & & .521 & .004 & Ho Rejected \\
$\begin{array}{l}\text { Performance } \\
\text { *Significant } \mathrm{p}<.05\end{array}$ & & & & & & & & \\
\hline
\end{tabular}

Table 6 shows the calculated r-value of .521 while p-value $(0.004)$ is less than the significance level $(0.05)$ for 78 degrees of freedom. Therefore, the hypothesis which states that there is no significant relationship between principals' supervisory technique and students' academic performance in Ilorin East Local Government Area, Kwara State is rejected. The finding reveals that there is significant relationship between principals' supervisory technique and students' academic performance in Ilorin East Local Government Area, Kwara State.

Ho $_{4}$ : There is no significant relationship between principals' motivational techniques and students' academic performance in Ilorin East Local Government Area, Kwara State

Table 7

Principals' Motivational Technique and Students' Academic Performance

\begin{tabular}{lllllllll}
\hline Variable & & $\mathrm{N}$ & $\overline{\mathrm{X}}$ & $\mathrm{SD}$ & $\mathrm{Df}$ & Cal r-value & P-value & Decision \\
\hline $\begin{array}{l}\text { Principals' } \\
\text { Technique }\end{array}$ & Motivational & 80 & 2.51 & .71 & & & & \\
& & & & & & & \\
$\begin{array}{l}\text { Students' } \\
\text { Performance }\end{array}$ & Academic & 80 & 2.41 & .70 & & .580 & .001 & Ho Rejected \\
\hline
\end{tabular}

$*$ Significant $\mathrm{p}<.05$

Table 7 shows the calculated r-value of .580 while p-value $(0.001)$ is less than the significance level $(0.05)$ for 78 degrees of freedom. Therefore, the hypothesis which states that there is 
no significant relationship between principals' motivational technique and students' academic performance in Ilorin East Local Government Area, Kwara State is rejected. The finding reveals that there is significant relationship between principals' motivational technique and students' academic performance in Ilorin East Local Government Area, Kwara State.

\section{CONCLUSION AND DISCUSSION}

The management techniques put in place by secondary school principals in Ilorin west local government area of Kwara State, Nigeria to a very large extent determines the performance of students in examination. The more rightly teachers are motivated by the principal the more they put forth their best in the discharge of their teaching responsibilities. Also, when school objectives are stated at the beginning of the school calendar by the principals, teachers work assiduously to ensure that the objectives are achievable by showing more commitments to their primary assignments. Furthermore, the more the school principal carry out supervisory activities in the areas of classroom observation, lesson note supervision and usage of appropriate teaching methodology the better and effective the performance of the teachers will be and this of course will translate into better performance on the part of the students.

On table 1, the mean ranking of the different management techniques suggests that if principals can make use of them it can aid students' academic performance in secondary schools in Ilorin East Local Government Area of Kwara State. It was discovered in table 2 that students' academic performance in Mathematics, Economics and Biology were found to be average overall. The findings on table 3 agreed with the view of Hoy and Miskel (2004) who observed that management techniques are logically programmed procedures used for the investigation and analysis of organizational problems. That is to say that without putting in place management techniques by principals in secondary schools, students' academic performance may not be guaranteed. The findings on table 4 is in harmony with Bua, Tyokyya and Kwaghbo (2016), Evans-obinna (2016) and Nwite (2016) who opined that elements of MBO are relevant and beneficial in achieving continuous improvement in secondary school management. The findings on table 5 is in agreement with Oluwole and Ivagher (2015) who stated that effective record keeping promotes accountability in schools. Findings on table 6 is also in consonance with Nakpodia (2011) and Ubulom, Nnunukwe and Dambo (2016) who opined that teachers' performance in secondary schools is significantly dependent on the aptitude of the principals to effectively conduct adequate and valuable supervision. The findings on table 7 agreed with the findings of Ige (2014) who asserted that prompt payment of teachers' salaries and allowances, payment of special salary for teachers, as well as the professionalization of teaching makes teachers to teach the students effectively.

\section{SUGGESTIONS}

Based on the findings obtained in this study, the following suggestions were made:

- The principals' should try as much as possible to adopt the suitable techniques applicable in a particular situation for the day to day running of the school.

- Teachers should be involved in the formulation of the objectives of the school for the effectiveness and achievement of the school goals.

- Principals should allow joint decision making and delegation of responsibilities in the schools for accurate outcomes of decisions made in schools.

- Principals should as much as possible adopt management by objective, supervisory, record keeping and motivation techniques. 


\section{REFERENCES}

Bua, F. T., Tyokyaa, C. \& Kwaghbo, M. T. (2016). Application of management by objective (MBO) on the effective administration of Universal Basic Education (UBE) Schools' Programme in Makurdi Education Zone of Benue State, Nigeria. International Journal of Innovative Education Research 4 (2),32-39

Evans-Obinna, R. N. (2016). Management by objective: A top down planning technique for effective Nigerian Secondary School Management in the 21st century. International Journal of Education, Learning and Development 4(3), 70-81

Ige, A. M (2014). Strategies for Motivation of Teachers for Effectiveness amid Universal Basic Education (UBE) Programme Implementation in Nigeria. European Journal of Academic Essays 1(6): 28-35

Nakpodia, E. D. (2011). Principals' supervisory aptitude of teachers' work performance in Delta State Secondary Schools, Nigeria. Journal of Research in Education and Society 2(1), 262-274

Nwite, O. (2016). Principal's application of management by objective in secondary schools in Ebonyi State, Nigeria. International Journal of Education, Learning and Development 4(6),19-30.

Oluwole, M. U and Ivagher, E. D. (2015). Record keeping and effective management of secondary schools in Zone B Senatorial District of Benue State, Nigeria. European Open Educational Research Journal 1(1) 1- 13 Available online at http://eurpub.com/Journals.php

Ubulom, W. J. Nnunukwe, A. D \& Dambo, B. I (2016). Supervisory strategies and effective instructional delivery in some Secondary Schools in Etche Local Government Area, Rivers State, Nigeria. International Journal of Innovative Development \& Policy Studies 4(1),22-33 
